\title{
Estimation of water requirement for different crops using CROPWAT model in Anantapur region
}

\author{
R. GANESH BABU, J. VEERANNA, K.N. RAJA KUMAR AND I. BHASKARA RAO
}

Article Chronicle :

Received :

20.09.2014;

Revised :

04.11.2014;

Accepted :

18.11.2014

Key Words : CROPWAT, Effective rainfall, ET0, Crop water requirement, Anantapur region
SUMMARY : Groundwater exploration for irrigation is a costly and scare input in agriculture and plays an important role in increasing food production. Due to over use of groundwater resources, it has become very important to estimate the Crop Water Requirement for different crops. Unscientific and injudicious application of groundwater in the Anantapur region resulted in depletion of the groundwater table. Anantapur region was chosen as the study area as its sever water problem. To achieve effective utilization of the groundwater resources, there is a need to estimate the crop water requirement for different crops at different management levels to accomplish effective irrigation management in the Ananthapur region. It is important that the water requirements of the crops are known. This study was carried out using CROPWAT 8.0 model. The information about climatic conditions, soil types and cropping pattern were obtained in the study area to estimate the crop water requirement under rainfed condition. The crop water requirement for the different crops of Anantapur region is very essential for effective utilization of the groundwater and also to be increase the crop yield. The maximum quantity of effective rainfall observed during the month of September as 79.5 per cent of the monthly rainfall i.e. $101.7 \mathrm{~mm}$ and average annual effective rainfall was estimated over the period 1985 to 2012 as $85.5 \%$ of the average annual rainfall i.e. $526 \mathrm{~mm}$ out of $615.4 \mathrm{~mm}$ of average annual rainfall. The crop water requirement for the groundnut Kharif and Rabi crops in the Anantapur region was estimated as $591.3 \mathrm{~mm}$ and $443.3 \mathrm{~mm}$, respectively and for the vegetables, cotton, rice, grains and maize in the Anantapur region are to be $594.1 \mathrm{~mm}, 878.6 \mathrm{~mm}, 1110.6 \mathrm{~mm}$, $699.9 \mathrm{~mm}$ and $679.3 \mathrm{~mm}$, respectively. Efficient water management becomes crucial and critical in normal or deficit rainfall years.

HOW TO CITE THIS ARTICLE : Babu, R. Ganesh, Veeranna, J., Kumar, K.N. Raja and Rao, I. Bhaskara (2014). Estimation of water requirement for different crops using CROPWAT model in Anantapur region. Asian J. Environ. Sci., 9(2): 75-79.
Author for correspondence :

\section{R. GANESH BABU}

Department of Soil and Water Engineering, College of Agricultural Engineering, BAPATLA (A.P.) INDIA

See end of the article for Coopted authors' 